\title{
New materials obtained by rubber recycling from industrial waste
}

\author{
Simona Sorina GABRIAN ${ }^{1}$ Sorin-Dumitru GROZAV ${ }^{2,}{ }^{*}$, Gabriel Nicodim CIUŞCĂ ${ }^{2}$, Vasile \\ Adrian CECLAN ${ }^{2}$, Antoniu TURCU ${ }^{3}$, and Stanislaw LEGUTKO ${ }^{4}$ \\ ${ }^{1}$ Technical University of Cluj Napoca, Department of Civil Engineering, ROMANIA \\ ${ }^{2}$ Technical University of Cluj Napoca, Manufacturing Engineering Department, ROMANIA \\ ${ }^{3}$ Technical University of Cluj Napoca, Manufacturing Electroenergetics and Management, \\ ROMANIA \\ ${ }^{4}$ Poznan University of Technology, Institute of Mechanical Technology, POLAND
}

\begin{abstract}
Solid waste management is one of the major environmental concerns nowadays. The present study covers the use of rubber and recycled plastics as replacement aggregates in concrete. Replacing the sand with plastics or rubber the compressive and tensile strength of the concrete decreases.. It was found that the concrete obtained by replacing a proportion not exceeding $9 \%$ of aggregates in the concrete recipe by rubber, can be used as a substitute for normal concrete, for instance in the building industry. The use of these materials in concrete comes from the environmental constraints in the safe disposal of the products. Big attention is being focused on the environment and safeguarding of natural resources and recycling of wastes materials.
\end{abstract}

\section{Introduction}

Research using by-products that contain recycled waste components, in order to enhance the properties of concrete have been done on for several years. In the past decades, efforts have been made to use industry by-products such as ash, ground granulated blast furnace slag (GGBS ), glass cullet, plastic etc., regarding civil constructions field.[1]. The potential applications of industry by-products in concrete are known to be partial replacement of aggregate or partial replacement of cement; depending on their chemical composition and grain size. The use of these materials in concrete comes from the increasing environmental issues, where a huge demand of safe disposal of these products is necessary.

Special attention should be paid to environmental protection and safeguarding of natural resources and recycling of waste materials. At the moment, many industries are producing a significant number of products which incorporate scrap (residues). In the last 10 years, various works concerning the use of several kinds of urban wastes in building materials industry were presented. Many researches have been extended the study on new types of wastes, materialized through investigations on particular aspects characteristic of the material. The addition of wastes, apart from the environmental benefits, in some cases- also produces good effects on the properties of final products. Accumulation of discarded waste

\footnotetext{
${ }^{*}$ Corresponding author: sorin.grozav@,tcm.utcluj.ro
} 
tire has been a major concern. The reason would be that the waste rubber is not easily biodegradable, even after a long period of landfill treatment.

Another new waste material shat is starting to be used in the concrete industry is recycled plastic. For solving the disposal of large amount of recycled plastic material, reuse of plastic in concrete industry is considered one of the possible applications. Recycled plastic can be used as aggregate in concrete. However, it is important to underline that reusing wastes is not yet economically advantageous, due to the high costs of transport and its effect on the total costs of production. Some research has focused on determining the mechanical, fracture and durability characteristics of high strength concrete, which contain recycled plastic particles [2]. Other researchers focused on determining the mechanical properties of these structures after exposure to high temperatures [3]. In other researches, the natural sand was replaced with plastic particles of the same volume [4]. Also these plastics can be reused for decoration of buildings [5]. Same research was to make a new material obtained from a mix of waste of carbon fibre, sand and an epoxy resin. The obtained material reevaluate the reinforcement material waste that is accumulated in the process of production, of the companies that produce fibre-reinforced composite material [6].

\section{Plastics recycling}

Recycling is the practice of recovering used materials from the waste stream and then incorporating those same materials into the manufacturing process. Recycling is one of the prominent issues in this environmentally conscious era. There are three main arguments for recycling: first, it preserves the precious natural resources; secondly, it minimizes the transportation and its associated costs; and thirdly, it avoids the environmental load caused by waste material, i.e. space requirement. The great strides have been made to increase recycling rates worldwide in recent years. Major considerations have been presented to support recycling all over the world, regarding the expansion and activation of the recycling system. The need to recycle plastics or organic is obvious. Plastic products, and rubber, do not decompose in landfills and are difficult to reduce in size. There are a few technological and economic constraints that currently limit the full and efficient recycling of plastic wastes into useful products. it would be great if these products could be reused in the production of consumer goods, by hydroforming or other methods, as other researchers have done [7].

\subsection{Recycling methods and construction applications}

Before using recycling of plastic or organic materials in concrete composites, several changes have to be made: including the use of chemical modification or a mechanical shredding. Plastic can be recycled by chemical modification or depolymerization. In this paper a mechanical crushing of rubber wastes will be presented and discussed." Please move the phrase at the end of introduction (Chemical Decomposition) and pyrolysis (thermal decomposition). However, it is much more complicated to chemically modify mixed plastics in order to produce useful and economical chemical feedstock. In this paper a mechanical crushing of rubber wastes will be presented and discussed.

\subsection{Mechanic recycling}

Mechanical recycling of plastics refers to processes which involve melting, shredding or granulation of waste plastics. Plastics must be sorted and washed using waste cleaner 
machine, all these prior to mechanical recycling. The technological process in which the assortment of plastic materials is made automatically uses various techniques such as X-ray fluorescence, infrared and near infrared spectroscopy, electrostatics and flotation. [8]

\section{Case study}

The measurements performed have tried to introduce ground rubber waste in two sorts of grit, more exactly aggregates of size $0-3 \mathrm{~mm}$ and $3-6 \mathrm{~mm}$, which replaced the fine portion of the concrete recipe (i.e. sand). Following sorting, the rubber is shredded in two sorts of grains, with the largest grain size equal with $0.6 \mathrm{~mm}$. For this study, concrete internal structure peculiar aspects were taken into account. Hardened concrete properties have a major importance for the design and execution of concrete structures. They are influenced by the proportion of various components in the mixture, the aggregates used, cement type, storage conditions (temperature, relative humidity), age and additions. $[9,10]$ Preparation of polymer concrete with rubber that does not differ essentially from that of ordinary concrete. Storage conditions of the polymer concrete are recommended to be in dry conditions.

For the reference concrete, without any addition of rubber, the results are obtained presented in Table 1.

Table 1. Reference concrete C $16 / 20$

\begin{tabular}{|c|c|c|c|c|}
\hline Body parts (test-pieces) & $\frac{\text { Exp. no: } 1}{\begin{array}{c}\text { C } 16 / 20(0 \% \\
\text { rubber })\end{array}}$ & $\begin{array}{c}\text { Exp. no: } 2 \\
\text { C } 16 / 20 \text { ( } 3 \\
\% \text { rubber } \\
\text { granules ) }\end{array}$ & $\begin{array}{c}\text { Exp. no: } 3 \\
\text { C 16/20 } \\
6 \% \\
\text { rubber ) }\end{array}$ & $\begin{array}{c}\text { Exp. no: } 4 \\
\text { C } 16 / 20 \\
(9 \% \\
\text { rubber ) }\end{array}$ \\
\hline CEM IV B (V-P) 42,5 N, kg/m 3 & 336 & 336 & 336 & 336 \\
\hline All aggregates, $\mathrm{kg} / \mathrm{m}^{3}$ & 1809 & 1809 & 1809 & 1809 \\
\hline $40 \%-$ Sand $(0-4), \mathrm{kg} / \mathrm{m}^{3}$ & 723,6 & 701,9 & 680,2 & 658,5 \\
\hline $\begin{array}{l}3 \% \text { - Rubber granulers ; } 1,5 \% \text { sort } \\
1-3 \mathrm{~mm} \text { and } 1,5 \% \text { sort } 3-6 \mathrm{~mm}\end{array}$ & - & 21,7 & - & \\
\hline $\begin{array}{l}6 \% \text { - Rubber ; } 3 \% \text { sort } 1-3 \mathrm{~mm} \text { and } \\
3 \% \text { sort } 3-6 \mathrm{~mm}\end{array}$ & - & - & 43,4 & \\
\hline $\begin{array}{l}9 \% \text { - Rubber ; } 4,5 \% \text { sort } 1-3 \mathrm{~mm} \\
\text { and } 4,5 \% \text { sort } 3-6 \mathrm{~mm}\end{array}$ & - & - & - & 65,1 \\
\hline $\begin{array}{l}20 \% \text { - Coarse aggregates }(4-8) \\
\mathrm{kg} / \mathrm{m}^{3}\end{array}$ & 361,8 & 361,8 & 361,8 & 361,8 \\
\hline $\begin{array}{l}40 \% \text { - Coarse aggregates }(8-16), \\
\mathrm{kg} / \mathrm{m}^{3}\end{array}$ & 723,6 & 723,6 & 723,6 & 723,6 \\
\hline \multicolumn{5}{|c|}{ Designed concrete } \\
\hline Water, $1 / \mathrm{m}^{3}$ & 198,24 & 198,24 & 198,24 & 198,24 \\
\hline Additive, $\mathrm{kg} / \mathrm{m}^{3}$ & 0 & 0 & 0 & 0 \\
\hline Ratio A / C & 0,59 & 0,59 & 0,59 & 0,59 \\
\hline Density ( design value ) $\left(\rho_{\mathrm{b}}\right), \mathrm{kg} / \mathrm{m}^{3}$ & 2343 & 2343 & 2343 & 2343 \\
\hline
\end{tabular}

Table 2. Properties of fresh concrete

\begin{tabular}{|l|c|c|c|c|}
\hline $\begin{array}{l}\text { Measurements on fresh } \\
\text { concrete }\end{array}$ & $\underline{\text { Exp. nr: 1 }}$ & $\underline{\text { Exp. nr: 2 }}$ & $\underline{\text { Exp. nr: 3 }}$ & $\underline{\text { Exp. nr: 4 }}$ \\
\hline Defended density $\left(\rho_{\mathrm{b}}\right), \mathrm{kg} / \mathrm{m}^{3}$ & 2334 & 2323 & 2308 & 2236 \\
& Making the & Making the & Making the & Making the \\
& pattern of & pattern of & pattern of & pattern of \\
concrete & concrete & concrete & concrete \\
& weighing V $=$ & weighing V $=$ & weighing V & weighing V \\
& 3,3751 & 3,3751 & $=3,3751$ & $=3,375$ \\
& & & (weighing & \\
\hline
\end{tabular}




\begin{tabular}{|l|l|l|l|l|}
\hline & & & $\begin{array}{l}\text { the pattern } \\
\text { with } \\
\text { concrete, V } \\
\text { tipar: 3,375 } \\
\text { 1) }\end{array}$ & \\
\hline Slump, mm & 60 (Figure 1) & 20 (Figure 2) & 0 (Figure 3) & 20 (Figure 4) \\
\hline $\begin{array}{l}\text { Visual Observations, slump } \\
\text { stipulation settlement ) }\end{array}$ & $\begin{array}{l}\text { Good } \\
\text { concrete, } \\
\text { slump ( } \\
\text { stipulation } \\
\text { settlement })\end{array}$ & $\begin{array}{l}\text { Concrete } \\
\text { consistent less } \\
\text { harsh than the } \\
\text { previous } \\
\text { density } \\
\text { greater than 3 } \\
\text { but less than } \\
\text { consistent } \\
\text { concrete } \\
\text { blank }\end{array}$ & $\begin{array}{l}\text { Sluggish ( } \\
\text { thick) } \\
\text { Concrete, } \\
\text { density } \\
\text { decreases, } \\
\text { exactly } \\
\text { what I } \\
\text { expected. }\end{array}$ & $\begin{array}{l}\text { Sluggish ( } \\
\text { thick) } \\
\text { Concrete, } \\
\text { density } \\
\text { decreases, } \\
\text { exactly what } \\
\text { I expected. }\end{array}$ \\
\hline
\end{tabular}

Table 3. Mechanical properties

\begin{tabular}{|c|c|c|c|c|}
\hline & \multirow{2}{*}{$\begin{array}{l}\text { Concrete test } \\
\text { specimen nr. }\end{array}$} & \multicolumn{2}{|c|}{$\begin{array}{c}\text { Compression strenght, } \\
\mathrm{N} / \mathrm{mm}^{2}\end{array}$} & \multirow{2}{*}{$\begin{array}{c}\text { Splitting resistance } \\
\mathrm{N} / \mathrm{mm}^{2}\end{array}$} \\
\hline & & 7 days & 28 days & \\
\hline \multirow{4}{*}{ Exp. nr. 1} & 1 & 21,1 & 31,8 & 3,18 \\
\hline & 2 & 20,0 & 31,7 & 3,43 \\
\hline & 3 & - & - & \\
\hline & Mean values & 20,6 & 31,8 & 3,31 \\
\hline \multirow{4}{*}{ Exp. nr. 2} & 1 & 19,0 & 23,4 & 2,19 \\
\hline & 2 & 17,5 & 28,1 & 2,47 \\
\hline & 3 & - & - & - \\
\hline & Mean values & 18,3 & 25,8 & 2,33 \\
\hline \multirow{4}{*}{ Exp. nr. 3} & 1 & 19,3 & 28,2 & 3,12 \\
\hline & 2 & 19,9 & 28,6 & 3,09 \\
\hline & 3 & - & - & - \\
\hline & Mean values & 19,6 & 28,4 & 3,06 \\
\hline \multirow{4}{*}{ Exp. nr. 4} & 1 & 14,7 & 18,7 & 2,36 \\
\hline & 2 & 14,3 & 19,1 & 2,08 \\
\hline & 3 & - & - & - \\
\hline & Mean values & 14,5 & 18,9 & 2,22 \\
\hline
\end{tabular}

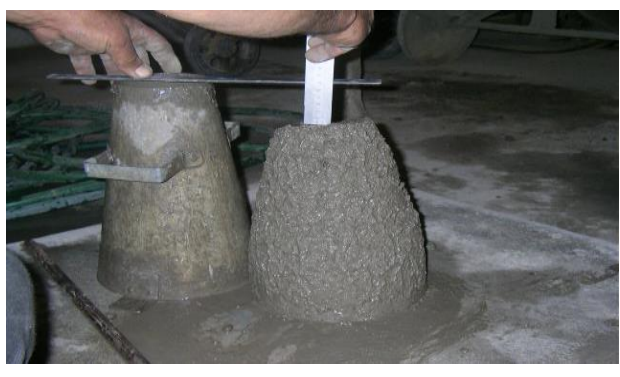

Fig. 1. Slump test for the reference concrete $(0$ $\%$ rubber)

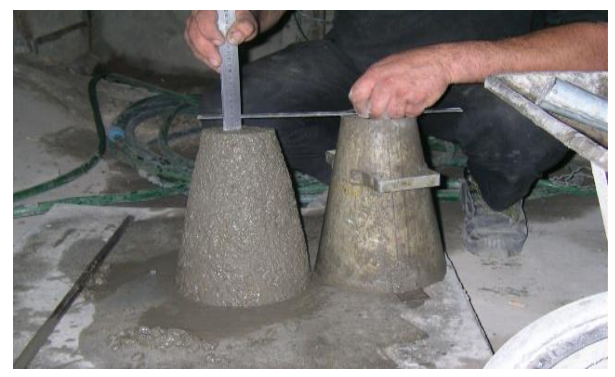

Fig. 2. Slump - test for the concrete with $3 \%$ of rubber

For the concrete with $3 \%$ rubber introduced in the mix we have the following data, Table 1. 


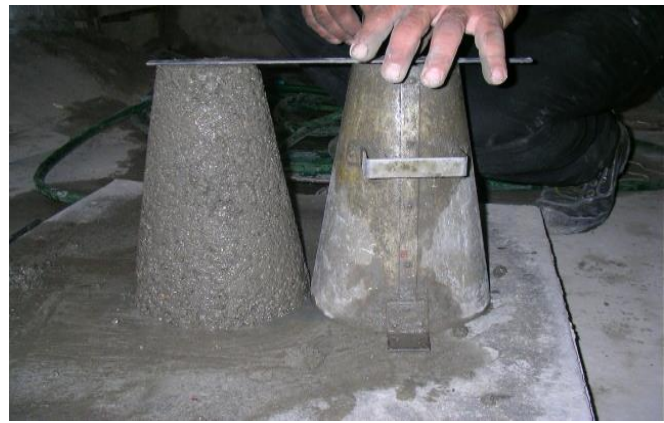

Fig. 3. Slump - test

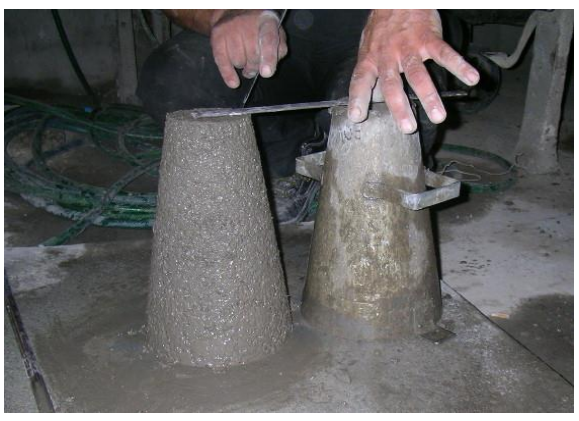

Fig. 4. Slump - test for the concrete with $9 \%$ of rubber

Next will be presented graphs of compression strength . To better understand the effects on the compression and tension strength if the concrete produced within this work the following graph are presented.

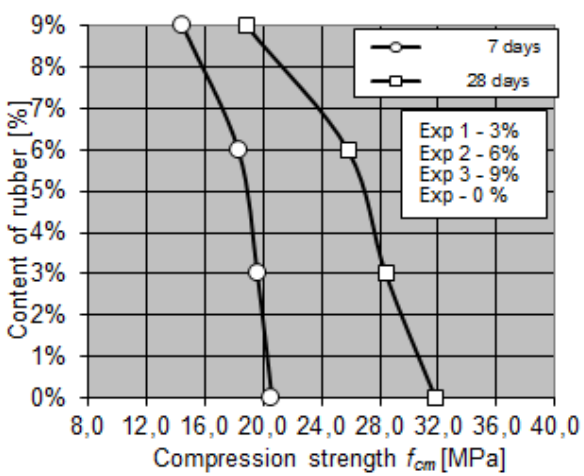

Fig. 5. Compression strength at 7 and 28 days with $0 \%, 3 \%, 6 \%, 9 \%$ waste rubber

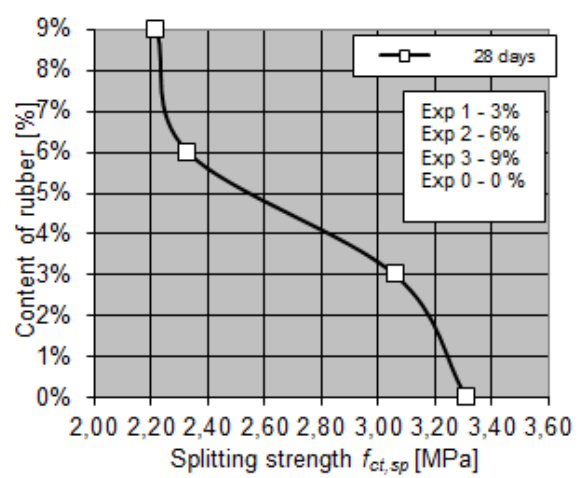

Fig. 6. Splitting strength at 28 days

Table 4. Values obtained from experiments on 7 and 28 days

\begin{tabular}{|c|c|c|c|c|}
\hline $\begin{array}{l}\text { Waste } \\
\text { rubber \% }\end{array}$ & $\mathrm{f}_{\mathrm{cm}}(7$ days $)$ & $\mathrm{f}_{\mathrm{cm}} / \mathrm{f}_{\mathrm{cm} 0}(7$ days $)$ & $\mathrm{f}_{\mathrm{cm}}$ (28 days) & $\mathrm{f}_{\mathrm{ct}, \mathrm{sp}}$ (28 days) \\
\hline $0 \%$ & 20,6 & 1,00 & 31,8 & 3,31 \\
\hline $3 \%$ & 19,6 & 0,95 & 28,4 & 3,06 \\
\hline $6 \%$ & 18,3 & 0,88 & 25,8 & 2,33 \\
\hline $9 \%$ & 14,5 & 0,70 & 18,9 & 2,22 \\
\hline
\end{tabular}

\section{Conclusions}

A decrease of concrete compressive strength has been observed at 7 days after casting. Values changed their values from 20.6 $\mathrm{MPa}$ (0\% rubber) to $14.5 \mathrm{MPa}$ (9\% rubber), depending on the content of rubber in the existent in the specimen.

At 28 days the decrease of compressive strength was from 31.8 ( $0 \%$ rubber) to $18.9(9 \%$ rubber). Splitting strength of after casting, a decrease of value from 3.31 ( $0 \%$ rubber) to 2.22 ( $9 \%$ rubber). 
As expected, a decrease of strength occurred. Though, one can conclude even on the background of this decrease, the results are fitted in a range covered by design codes and their recommendations class C 16/20 experiments with $3 \%$ waste rubber and, possibly $6 \%$ waste rubber also $9 \%$ in what the structural use is very limited the minim concrete in EC2, is the class C $12 / 15$.

This proposal of new concrete fits the directions of the new programmer regarding sustaibinility in construction engineering due to its characteristics. On one hand, on the background of the environmental trends regarding the policy of waste disposal, the usage of this concrete can lead to the reduction of high quantity of wastes [11]. On the other hand, the replacement of the aggregates with rubber lowers a part of the production costs.

A decrease of compressive strength can be observed - You can see a decrease after experiment.

\section{References}

1. Maneek H.,Shweta G., Laboratory investigations of the properties of concrete containing recycled plastic aggregates , 2008.

2. Faraj RH., Sherwani AFH., Daraei A., Mechanical, fracture and durability properties of self-compacting high strength concrete containing recycled polypropylene plastic particles, Journal Of Building Engineering, Vol 25, 2019, DOI: 10.1016/j.jobe.2019.100808

3. Nematzadeh M., Mousavimehr M., Residual Compressive Stress-Strain Relationship for Hybrid Recycled PET-Crumb Rubber Aggregate Concrete after Exposure to Elevated Temperatures, Journal Of Materials In Civil Engineering, Volume: 31 Issue: 8, 2019, DOI: 10.1061/(ASCE)MT.1943-5533.0002749

4. Badache A., Benosman AS., Senhadji Y., Mouli M., Thermo-physical and mechanical characteristics of sand-based lightweight composite mortars with recycled high-density polyethylene (HDPE), Construction and Building Materials, Volume: 163 Pages: 4052, 2018, DOI: 10.1016/j.conbuildmat.2017.12.069.

5. Emilia Sabău, Chapter Recycling of Polymeric Composite Materials, Book Product Lifecycle Management - Terminology and Applications, IntechOpen, 2018, ISBN 9781-78984-543-3, DOI:10.5772/intechopen.81281,

6. Ceclan VA., Bere P., Borzan M., Grozav S., Borzan C., Development of Environmental Technology for Carbon Fibre Reinforced Materials Recycling, Materiale Plastice, Volume: 50 Issue: 2 Pages: 79-83, 2013

7. VA Ceclan, N Bâlc, S Grozav, P Bere, CS Borzan., Quality of the hydroformed tubular parts., Advanced Engineering Forum 8, 215-224, 2013

8. Baltateanu D.,Sima M., Global Environmental Changes. Natural hazards and Technology Credits Publishing House, Bucharest, 2006

9. Kiram B.V.K.,Prakash P., Use of waste Plastics in cement concrete pavement, 2009

10. Prakash P.,Study of waste Plastics as Composite Materials in cement Concrete construction. Proceedings of Thermic 2006.

11. IS: 456 - 2000 Plain and Reinforces Concrete Code of Practice Bureau of Indian Standards, New Delhi. 